\title{
THE COLLAPSE OF THE ICELANDIC BANKING SYSTEM AND THE (DIS)HONEST AND/OR (IN)COMPETENT RESPONSE OF THE INTERNATIONAL COMMUNITY
}

\author{
HiLMAR PÓR HiLMARSSON ${ }^{1}$
}

University of Akureyri (Iceland)

\begin{abstract}
The 2008 global economic and financial crisis hit hard in Iceland. During the crisis its three largest banks all collapsed in just a few days with severe consequences for the economy and the people. Prior to the crisis, Iceland, a high income OECD country, had experienced strong growth and unprecedented expansion in overseas investments and activities, especially in the financial sector. This article focuses on the actions of the international community when the Icelandic authorities, during a period of great uncertainty, sought assistance to protect the Icelandic economy before the banking system fell. The methodology used in this article is the case study method. Compared to other research methods, a case study enables the researcher to examine the issues involved in greater depth. Arguably, the governments of the Netherlands and the UK tried to fake reality by suggesting that the Icelandic government, i.e. Icelandic taxpayers, should be made responsible for paying the debts of private banks. The EFTA Court ruling confirms that Iceland did not have this responsibility. In retrospect one can argue that the EU showed dishonesty by supporting the Netherlands and the UK in demanding a sovereign guarantee for failed private banks. The Icelandic banking expansion exposed weaknesses in EU integration and may also confirm a certain incompetence within the EU in designing an EU-wide banking system.

KEYWORDS: Economic and financial crisis, economic policy, international expansion of firms, risk management.
\end{abstract}

JEL CODES: F21, G32, H12

Introduction

The global economic and financial crisis that started in the fall of 2008 hit the Icelandic economy hard. During this crisis its three largest banks (Glitnir, Kaupthing, and Landsbanki) ${ }^{2}$ all collapsed with dire consequences for the economy and the people. Prior to the crisis Iceland had experienced strong economic growth and unprecedented expansion in cross border investments and activities, especially in the financial sector.

During a crisis of this magnitude the government has an important role to play, including action to intervene in developments that may endanger economic stability and pose an imminent threat to the welfare of the nation. This includes taking action if developments in a particular sector, such as the financial sector, make the economy extremely vulnerable (see for example; Hilmarsson, 2013a and 2013b).

The international community also has a role to play in assisting a small country during a crisis, especially since this was a crisis on a global scale, and because the Icelandic banking expansion was at least partly the result of a flaw in European integration. Other countries also need to behave responsibly, as failure to do so not only affects the country where the banking system falls, but also their own citizens. The international

1 Hilmar Pór Hilmarsson - Ph.D. Professor, School of Business and Science, University of Akureyri, Iceland. Scientific interests: finance, international finance

E-mail: hilmar@unak.is

Tel. +3548498380

2 These three banks accounted for about $85 \%$ of Iceland's financial system. 
community should also refrain from using strong-arm tactics against small states and trying to impose unjust and illegal actions.

This article will focus on the responsibility of the international community. Did the international community, including the European Union, take appropriate action when the Icelandic banks expanded with investments and operations overseas? Was inaction a problem? Can the international community be charged with attempting to fake reality, i.e. pretend that Iceland had responsibilities that it did not have? Is it possible that the international community was honest but demonstrated incompetence and is therefore not trustworthy? Put differently, during the crisis a failure of European integration was exposed, but larger countries, the UK and the Netherlands, supported by the EU tried to use force to have a small country suffer the consequences.

The proposition in this article is that small countries like Iceland benefit from being members of multilateral arrangements such as the European Economic Area (EEA) and generally benefit from European integration and open access to markets, including financial markets. When crisis hits, small states such as Iceland also benefit from being part of a group of nations like the Nordic countries and are likely to receive assistance from nations with whom it has friendly political relations.

The foreign officials discussed in this article are primarily central bank officials (as well as representatives of international organizations, including the European Union and international financial institutions). All these officials are mentioned in the report of the Special Investigation Commission of the Parliament of Iceland published in April 2010.

\section{Methodology}

The methodology used in this article is the case study method. Compared to other research methods, a case study enables the researcher to examine the issues involved in greater depth. According to Yin (Yin, 2009: 101-102) six sources of evidence are most commonly used in case studies. These are: documentation, archival records, interviews, direct observations, participant-observation, and physical artifacts. Each of these sources has advantages and disadvantages and according to Yin one should "note that no single source has a complete advantage over all the others. In fact, the various sources are highly complementary, and a good case study will therefore want to use as many sources as possible" (Yin, 2009: 101). Among the sources of evidence used for the analysis in this article are documentation/secondary data, including reports and scholarly literature, articles and books. The author also exchanged emails with scholars in the field of economics, political science, public administration and philosophy / ethics. These communications when referred to are documented in footnotes. Direct observation also plays a role in this article as the author draws on his experience and observations while living in Iceland prior to and during the crisis. However, preference was given to using well documented evidence that is publicly available and listed in the references. This case study does not present results that can be evaluated on the basis of statistical significance and one should be careful about generalizing or projecting the findings of one case study onto another case or situation. However, some lessons from the study could have wider relevance than for Iceland only. This is especially true for small countries with a large banking sector, using their own currency, and with limited fiscal space to support the banks during a crisis.

\section{Definitions, theoretical considerations and research questions}

The word honesty is sometimes mentioned in the economics, political science and public administration literature, but the author has so far not found a definition of what exactly is meant by honesty in these fields. Contact was made with economists, public administration specialists, political scientists and lawyers without finding a definition of what honesty means in those professions. A literature review in these fields also did not yield a definition. Several reports and scholarly articles reviewed mention honesty, but without providing a definition. A key report on the sources of sustained economic growth, i.e., the "Growth Report - Strategies for Sustained Growth and Inclusive Development" for example mentions honesty as important in the public 
sector and one can find statements like: "A culture of honest public service must be fostered and maintained", and: "But stable, honest, and effective government is critical in the long run" (Growth Report, 2008, p. 4-5). However, there is no definition of what honesty is, and in fact, a commission that included two Nobel Prize winning economists, as well as many other internationally recognized scholars and policy makers, never defined what honesty is ${ }^{3}$. This seems to be a common and troubling problem in that the word honesty is used without specifying its exact meaning.

The report of the Special Investigation Commission (SIC), established by the Icelandic parliament, the Alpingi, to investigate and analyze the processes leading to the collapse of the three main banks in Iceland, mentions honesty. One can, for example, find a quote such as "honesty is the best policy". But honesty is never defined. Furthermore the working group on ethics under the SIC did not make any judgement as to whether or not government or international officials showed dishonesty in their work prior to the banking crisis $^{4}$.

In this article honesty ${ }^{5}$ is defined with Ayn Rand's discussion of honesty in mind. Rand's honesty is a refusal to pretend that facts from reality are other than they are. According to Rand one should not fake reality for others or oneself. Rand states that the virtue of honesty is that "one must never attempt to fake reality in any manner" (Rand, 1961: n.p). Honesty "is the recognition of the fact that you cannot fake existence" and "is the recognition of the fact that the unreal is unreal and can have no value" (Rand, n.d: n.p). In other words what is not so is not so. Things must be understood for what they are.

Tara Smith devotes a chapter to honesty in her outstanding book "Ayn Rand's Normative Ethics - The Virtuous Egoist". According to Professor Smith, faking "refers to familiar forms of pretending that things are other than they are, such as deliberately omitting pertinent information about a subject, covering something up, or twisting one's account of a situation to foster misleading impressions" ${ }^{6}$ (Smith, 2006: 76). And she goes on to note that "[m]isrepresenting facts does not change them. However successfully one might fool another person, faking is ultimately futile" (Smith, 2006: 105). Pretending that things are other than they are does not make them other than they are. As Tara Smith notes, "[d]ishonesty can sometimes fool other people, but it cannot fool reality" (Smith, 2006: 81). "Facing reality is in a person's interest, even when certain aspects of reality are threatening, because it allows him to proceed rationally - realistically - and thus with the chance of overcoming threats..." (Smith, 2006: 105).

In addition to Rand's definition, and Smith's discussion, of honesty, the following statement from Susan Rose-Ackerman is also used in this article: "Honesty is an important substantive value with a close connection to trust. Honesty implies both truth-telling and responsible behavior that seeks to abide by the rules. One may trust another person to behave honestly, but honesty is not identical to trustworthiness. A person may be honest but incompetent and so not worthy of trust" (Rose-Ackerman, 2001: 526).

Ayn Rand's definition and Rose-Ackerman's observation triggered the following issues that need to be kept in mind when answering the research questions stated in the introduction above:

- Was the international community (governments including central banks as well as international organizations) dishonest in its response to the Icelandic authorities when they requested assistance to rescue the banking system? This question needs to be addressed since attempts were made to have

According to an email from Professor Danny Lepziger, Commission Vice Chair to the author, received on August $13,2012$.

4 According to an email from Professor Vilhjálmur Árnason to the author received on July 27, 2012. Professor Árnason was the leader of a special three-person working group on ethics that was mandated in the Special Investigation Commission legislation by the Alpingi.

5 When searching for a definition of honesty the author was in contact with Professor Tara A. Smith who recommended Ayn Rand's discussion of honesty in Galt's speech, as well as in her essay "The Objectivist Ethics," which is in The Virtue of Selfishness. For fuller elaboration, see Leonard Peikoff's discussion of honesty in Objectivism: The Philosophy of Ayn Rand, pages 267-276. Professor Smith also devotes a chapter to honesty in her book Ayn Rand's Normative Ethics: The Virtuous Egoist. Email received from Professor Smith September 17, 2012.

6 Tara Smith also refers to Peikoff's Objectivism, p. 267-268 where he explains that honesty is its obverse: the rejection of unreality, the recognition that only existence exists. 
the Icelandic government give a sovereign guarantee for foreign deposits in failed private banks beyond the amount the accounts had been insured for. Did the international community seek to fake reality by deliberately and falsely claiming that Iceland had a responsibility that it did not have? Such actions could have serious consequences, not only for Iceland, but also for citizens of other countries involved. Dishonesty here could include deliberately omitting pertinent information or twisting one's account of a situation to foster a misleading impression.

- Was the international community incompetent in the sense that it did not understand that flaws in European banking regulations had resulted in excessive cross border banking expansion in Europe that could contribute to, or even cause, a global banking crisis?

\section{The Central Bank of Iceland and its pre-crisis attempt to rescue} the Icelandic banking system

From March to early October 2008 the Central Bank of Iceland (CBI) made desperate attempts to increase its foreign exchange reserves. The communications, including emails, between the CBI and other central banks approached were documented and made public by the Special Investigation Commission (SIC) that delivered its report to the Alpingi on April 12, 2010.

According to the SIC report, the Bank of England was first approached in March 2008 because of large Icelandic cross border bank operations in the UK. The CBI requested a bilateral currency swap arrangement with the Bank of England. The Bank of England appeared to be suspicious about the intentions of the CBI and wanted clarification of what the funds would be used for. In late March 2008 a formal letter was written and sent from the CBI to the European Central Bank (ECB). The response to that letter was to ask if the CBI had approached the IMF, the Bank of International Settlements, and other central banks, in addition to the Bank of England. It is notable that in March 2008 the ECB thought that the IMF should be contacted.

During the IMF Spring Meetings in Washington DC in April 2008, CBI representatives met with Nordic central bank officials, including central bank governors. According to the SIC report it appears that the governor of the Swedish central bank, the Swedish Riksbank, Stefan Ingves, had been given the responsibility of coordinating reactions to the CBI request on behalf of the Nordic central bank governors.

It is clear that Mr. Ingves did not have much confidence in the CBI representatives. In a letter to the SIC on January 22, 2010 he commented that "[M]y own impression was that the Icelandic representatives were stressed, not particularly well prepared, and not fully appreciated [sic] the risks at hand" (Rannsóknarnefnd Alpingis, 2010: 170). Discussion also arose about conditions in the event of financial assistance from the Nordic countries to Iceland, showing that at this stage not much trust existed between the CBI and the other Nordic central banks and not much trust in the government of Iceland either.

During the 2008 IMF Spring Meetings the governor of the Bank of England, Mervyn King, stated that it was necessary for the CIB to clarify how the swap arrangements would be used. He also asked what the government would do if a run on the banks occurred the next day. This shows that the Bank of England thought that the Icelandic banking system could be at risk of collapsing at any time. Finally, Timothy F. Geithner, president of the Federal Reserve Bank of New York, was approached. He had already been in contact with other central bank governors and is reported to have "had doubts" explaining that assistance to Iceland would need to be large to have the intended effects, more than US\$10 billion.

On April 23, 2008 Mr. King sent a letter to Davíx Oddsson, governor of the CBI, in which he said that in his "judgement, the only solution to this problem is a programme to be implemented speedily to reduce significantly the size of the Icelandic banking system" (Rannsóknarnefnd Alpingis, 2010: 172). Furthermore he stated that he "would very much like to discuss how the international community could offer help to Iceland in respect of designing such a solution by raising the matter at the dinner of G10 Central Bank Governors to be held in Basel on 4 May. I have spoken about this with Stefan Ingves, Governor of the Riksbank in Sweden, and we shall both be requesting a discussion at the dinner" (Rannsóknarnefnd Alpingis, 2010: 173). In his letter in response, Mr. Oddsson asked Mr. King to reconsider and stated that "[t]he Icelandic banks are 
well capitalised but they are dealing with a problem of perception" (Rannsóknarnefnd Alpingis, 2010: 174). Mervyn King did not respond to that letter.

On May 16, 2008 a currency swap arrangement between the CBI and the Nordic central banks was signed under conditions agreed to by the CBI governors and key Icelandic ministers (the prime minister, the foreign minister and the finance minister). None of the major central banks were involved and the amount was a modest 1.5 billion Euro. On June 6, $2008 \mathrm{Mr}$. Oddsson wrote a letter to Timothy F. Geithner informing him that in his opinion the currency swap agreements with the Nordic countries had been successful and "[a]lso, as demonstrated by the Nordic facility, the size of the arrangement is not necessarily a decisive issue at this juncture. In my view the perception of strong allies is more important. An arrangement with the Fed would therefore be of monumental significance. I would very much appreciate it if you would give the matter some further thought and be in touch. We would be happy to provide any further information that you would deem helpful." [...] "The perception of strong and far reaching alliances is more important than size. The perception of a lack of allies may have [the] opposite effect" (Rannsóknarnefnd Alpingis, 2010: 179).

At the end of September 2008, currency swap agreements between the United States and the Nordic countries (Denmark, Norway and Sweden) were announced - Iceland was not included. The same day Mr. Oddsson wrote to Mr. Geithner that "[t]he announcement this morning of the new currency swaps appears to have enhanced confidence for the participating countries. However, given the perception that the Nordics are one, including Iceland, the new agreement may appear to the markets as having left us in the lurch" (Rannsóknarnefnd Alpingis, 2010: 179). The Federal Reserve was asked to reconsider, but in early October the final answer was no.

At this point in time Iceland was completely isolated. The three largest Icelandic Banks collapsed in early October 2008 and Iceland had no other option but to approach the IMF. An agreement between the government of Iceland and the IMF was signed on October 24, 2008.

\section{Did the response of the international community show (dis)honesty} and / or (in)competence?

Considerable research has been done regarding the pre-crisis actions and inactions of the government of Iceland (see, for example, Hilmarsson, 2013a and 2013b). Less attention has been given to the actions and the inactions of the foreign governments and officials approached by the Icelandic government for assistance before its banking sector collapsed. Were they honest in their actions vis-à-vis their own citizens or the citizens of Iceland? This is a question that merits research and would, in fact, merit a separate investigation. Is it possible that they acted honestly but were incompetent and therefore not trustworthy e.g. not understanding or recognizing flaws in European integration and the possible consequences?

Before the crisis hit, the Icelandic banks had, as discussed above, expanded their operations aggressively, including into the UK and the Netherlands. This included the so called "Icesave" accounts, which were offering interest rates that were considered favorable by many. As Joseph E. Stiglitz states in his book Freefall, "[t]he depositors foolishly thought there was a "free lunch': they could get higher returns without risk" (Stiglitz, 2010: 23). They may also have thought that their own governments in the UK and the Netherlands were doing their regulatory job. When these privately owned Icelandic banks could no longer honor their commitments during the 2008 crisis the UK used strong-arm tactics, including invoking an anti-terrorist law against Iceland and insisting that Icelandic taxpayers bail out depositors from the UK and the Netherlands beyond the amounts the accounts had been insured for. As Stiglitz asks: "Why should Iceland's taxpayers be made to pay for the failure of a private bank, especially when the foreign regulators had failed to do their job of protecting their own citizens?" (Stiglitz, 2010: 23). Many Icelanders asked the same question.

As Stiglitz argues, the banking expansion in Iceland "exposed a fundamental flaw in European integration" (Stiglitz, 2010: 23). In "the single market" any European bank could operate in any EU country and the responsibility for regulation was put on the home country (in this case Iceland). If the home country failed to do its job the citizens of other countries could lose large sums of money: "Europe didn't want to think 
about this and its profound implications; better simply make little Iceland pick up the tab, an amount some put as much as 100 percent of the country's GDP" (Stiglitz, 2010: 23). This is a sharp criticism of the EU and coming from a Nobel Prizewinning economist. An investigation into the actions and inactions of foreign government and international officials, including EU officials, would be justified and those individuals and the institutions involved should be held accountable.

After the crisis hit, the Icelandic government twice reached a settlement on the Icesave accounts that were approved by the majority of the Icelandic parliament, the Alpingi. The president of Iceland twice refused to sign the legislation approved by the Alpingi. This triggered two national referendums in which the people overwhelmingly voted no. Finally the EFTA Court ruled that there was no legal basis for the case of Britain, the Netherlands and the EU against Iceland.

The president of Iceland described these events well in a speech at a meeting of OECD ambassadors in Paris on 27 February 2013: "And, when we faced the (...) Icesave dispute in which the Governments of the United Kingdom and the Netherlands, supported by all EU governments and others, demanded that the ordinary people of Iceland - fishermen, farmers, teachers, nurses - should shoulder through their taxes the debts of a failed private bank - we had to choose between the financial interests as they were presented by the established leadership of Europe and the democratic will of the Icelandic nation and decided to allow democracy to prevail.

Following the two referendums, in which the people overwhelmingly voted No, the economy started to recover, becoming healthier with each quarter. The financial doomsayers, whether experts or leaders, who advised strongly against the democratic will of the people turned out to be entirely wrong in their analysis and predictions; a result which certainly should serve as a challenge to many of the policies which are still being advocated and followed in many countries.

When the EFTA Court last month ruled that there was no legal basis for the case of Britain, the Netherlands and the EU against Iceland, it became clear that in addition to the democratic will of the people, justice and the rule of law was also on our side" (Grímsson, 2013: 5-6).

Trade relations between Iceland and the UK have been important for both nations for decades. Political relations have, however, sometimes been tense. When Iceland expanded its fisheries territory to 200 miles, the UK government sent its navy into Icelandic territory, an unprecedented act given that both Iceland and the UK are NATO member states. The dispute over fisheries territories, the so-called Cod Wars, was long with dangerous friction between the Icelandic Coast Guard and the British Royal Navy. Again, in this case too the UK used strong-arm tactics, in essence behaving like colonizers against a colony.

Recently the UK government has expressed strong interest in purchasing electricity from Iceland via a submarine cable to the UK. This would help the UK meet its growing energy needs and be part of its transition to clean energy. A submarine cable would be a large and long term investment. Moreover, if successful it could benefit both nations. But several issues need to be settled, including energy prices, energy quantity, contract duration, as well as funding and ownership of the cable. Given past tensions the question remains whether these two nations can cooperate on such a large project so as to be mutually beneficial.

The experience that Iceland underwent during the crisis means that Iceland needs to rethink its foreign policy and how it relates to other nations that have often been considered friendly. The UK has been hostile towards Iceland before, so its refusal to assist followed by aggressive action, poorly disguised as being under an anti-terrorist act, should not come as a surprise. Iceland also perhaps naïvely tends to consider the other Nordic countries as big brothers who would help their little brother if things went wrong. History shows that the Nordic countries think primarily of their own interests when crisis hits and their own interest would often be to protect their relations with larger nations like the UK rather than help the smallest "Nordic brother." This was also the case during the Cod Wars. Relations with the US have also fundamentally changed. Had the financial crisis hit during the Cold War the response from the US would probably have been far different from what it turned out to be post Cold War.

Given the verdict of the EFTA Court it is now clear that Iceland did not have the responsibility to provide a sovereign guarantee for the failed private banks. Considering the demands from the UK and the Nether- 
lands, supported by the EU, one could argue that they behaved dishonestly in deliberately and falsely claiming that Iceland had responsibilities that it did not have. The possibility also arises that these parties failed to understand pre-crisis weaknesses in EU regulation and their reaction should rather be labeled as incompetence than dishonesty. In that case more international efforts should have been made to assist Iceland when weaknesses in the EU financial system materialized.

\section{Conclusions}

Clearly, by promoting the idea that Iceland should become an international financial center, the government of Iceland did express strong faith in the banking sector and did encourage its expansion. The president of Iceland was also a strong supporter of expansion by the three largest banks as can be seen from the speeches he made overseas. The government generally welcomed the expansion of the banks but did not take credible measures to protect the economy in the event of a banking crisis. Possibly, the collapse of the banks could have been prevented had the government (the prime minister and the cabinet) taken a drastic measure in the shape of insistence on downsizing the banking sector or relocating most of its cross border operations (Hilmarsson, 2013a and 2013b).

When the Central Bank of Iceland made attempts to increase its foreign exchange reserves in March 2008, there was little trust between the CBI and other central banks. It was logical that the CBI would first contact the Bank of England given the large operations of Icelandic banks in the UK. Both institutions had an interest in finding a solution if possible. The Bank of England offered its assistance to approach the "international community" to help reduce the size of the Icelandic banks, but it was unclear how this could be done and Iceland had few reasons to trust the Bank of England. As discussed above, mistakes were made in Iceland, but it is also clear that the UK has a long history of hostility towards Iceland, for example during the "Cod Wars".

When the banking system fell in Iceland the UK again used strong-arm tactics: invoking an anti-terrorist law against Iceland. Given this history pre- and post-crisis, Iceland needs to be careful in its relations with the UK. The government of Iceland twice reached a settlement on the Icesave accounts, settlements rejected in two national referendums.

Arguably, the governments of the Netherlands and the UK tried to fake reality by suggesting that the Icelandic government, i.e. Icelandic taxpayers, should be made responsible for paying the debts of private banks. The EFTA Court ruling confirms that Iceland did not have this responsibility. In retrospect one can argue that the EU showed dishonesty by supporting the Netherlands and the UK in demanding a sovereign guarantee for failed private banks. The Icelandic banking expansion exposed weaknesses in EU integration and may also confirm a certain incompetence within the EU in designing an EU-wide banking system.

The Nordic countries were hesitant to support Iceland during the crisis. Their relationship with the Netherlands and the UK is much more important, politically and economically, than their relationship with Iceland. The close coordination between the Riksbank of Sweden and the Bank of England on how to respond to Iceland's problems shows that the Nordic countries first and foremost take care of their own interests during times of crisis. This can hardly be considered dishonesty but it shows that they are not trustworthy protectors of Iceland's interests.

Additionally, the Nordic countries had enough problems on their own hands: being by far the largest owner of the banking systems in the Baltic States made them vulnerable and the Scandinavian banking systems were closely interlinked. A Baltic banking crisis could have triggered a Scandinavian banking crisis that could then have destabilized the fragile European Banking system (Hilmarsson, 2014). The Baltic and Scandinavian banking systems still remain heavily interconnected and vulnerable post-crisis.

The US could be counted on as Iceland's strong ally during the Cold War but weaker political ties after the Cold War meant that they no longer want to get involved. Following its own interest can hardly be considered dishonest but also shows that Iceland cannot rely on the US for assistance during times of crisis. 
In retrospect Iceland was lucky that its banking system was not rescued by major central banks as this could have brought the debt level of the country to an unsustainable level. Iceland was fortunate not to have to serve the interest of the Euro area and the Icesave dispute was resolved in two national referendums and eventually in the EFTA Court. However dishonest and incompetent the Icelandic and foreign officials may have been, democracy found a way to ameliorate what could have been a truly catastrophic situation for Iceland.

\title{
References
}

Grímsson, Ó. R. (2013). A clean energy economy lessons from Iceland A Speech by the President of Iceland Ólafur Ragnar Grimsson at a meeting of OECD Ambassadors OECD Paris. 27 February. Available at: http://www.forseti. is/media/PDF/2013_02_27_OECD_CleanEnergy.pdf [accessed on January 3, 2015].

Growth Report - Strategies for Sustained Growth and Inclusive Development. (2008). International Bank for Reconstruction and Development / The World Bank 2008. Available at: http://cgd.s3.amazonaws.com/GrowthReportComplete.pdf [accessed on February 20, 2015].

Hilmarsson, H. P. (2014). Small States in a Global Economy - Crisis, Cooperation and Contributions. Series on Economic Issues, Problems and Perspectives. Nova Science Publishers, Inc. New York.

Hilmarsson, H. P. (2013a). The Banking Crisis in Iceland: Did the Government Pretend that Facts from Reality were Other than they Were? In: T. Vissak, M. Vadi (eds.). (Dis)Honesty in Management. Advanced Series in Management, Vol. 10. Emerald Group Publishing Limited, p. 61-84. DOI:10.1108/S1877-6361(2013)0000010008.

Hilmarsson, H. P. (2013b). Small states and big banks - the case of Iceland. Baltic Journal of Economics, Vol. 1, p. 31-48. Available at: http://www.biceps.org/assets/docs/bje/bje2013_no1/Policy_paper_2 [accessed on February 7, 2015].

Peikoff, L. (1991). Objectivism: The Philosophy of Ayn Rand. New York: Penguin, 1991.

Rand, A. (n.d.). John Galt Speech. Available at: http://www.amberandchaos.net/?page_id=73 [accessed on January 26, 2015].

Rand, A. (1961). The Objectivist Ethics. Paper delivered by Ayn Rand at the University of Wisconsin Symposium on "Ethics in Our Time" in Madison, Wisconsin, on February 9, 1961. Available at: http://www.nscp.org/uploaded files/1/files/IA-Lab-3-Supplemental.pdf [accessed on January 5, 2015].

Rannsóknarnefnd, A. (2010). Aðdragandi og orsakir falls islensku bankanna 2008 og tengdir atburðir. Bindi 1 og 8. Available at: http://www.rannsoknarnefnd.is/ [accessed on March 3, 2015].

Rose-Ackerman, S. (2001). Trust, honesty and corruption: reflection on the state-building process. European Journal of Sociology, Vol. 42, Issue 3, December, p. 526-570.

Smith, T. (2006). Ayn Rand's Normative Ethics. The Virtuous Egoist. Cambridge University Press.

Stiglitz, J. E. (2010). Freefall: America, free markets, and the sinking of the world economy. WW Norton \& Company. Yin, R. K. (2009). Case Study Research. Design and Methods. 4th ed. Vol. 5. California: SAGE Inc.

\section{ISLANDIJOS BANKŲ SISTEMOS GRIUVIMAS IR (NE)SĄŽININGA, (NE)ATSAKINGA TARPTAUTINË BENDRUOMENE}

\author{
HiLmar Pór HiLmarsSon \\ Akureyri universitetas (Islandija)
}

\section{Santrauka}

2008 metų ekonominė krizè sudavė skaudų smūgị Islandijos ekonomikai. Per kelias dienas žlugo trys didžiausi bankai. Iki krizès Islandija buvo viena iš šalių, kurios pajamos buvo neblogos, o ekonomika stabiliai auganti, ypač finansų srityje dèl užsienio investicijų. Šiame straipsnyje analizuojami tarptautinès bendruomenès veiksmai, ịvykus ekonominei krizei, kaip reagavo Islandijos vyriausybė, siekdama apsisaugoti nuo finansinès griūties. Straipsnyje taikytas atvejo analizès metodas. Lyginant šị metodą su kitais, atvejo 
analizės metodas padeda išsamiau išanalizuoti buvusią situaciją, ịvertinant ịvairius situacijos aspektus. Verta paminèti, kad Nyderlandų ir Didžiosios Britanijos vyriausybės bandè paveikti Islandijos vyriausybę, kad visus privačių bankų užsienio valstybių nuostolius padengtų Islandijos vyriausybė, kitaip tariant, Islandijos visuomenè - mokesčių mokètojai. Bandyta teigti, kad Islandija neprisiima atsakomybès. Vis dèlto ES elgèsi nesąžiningai, palaikydama Nyderlandų ir Didžiosios Britanijos privačius bankus. Tai parodė Islandijos bankų sistemos silpnybes integruojantis ị ES, kartu ir ES bankų sistemos nekompetentingumą.

PAGRINDINIAI ŽODŽIAI: ekonominè ir finansine krizè, ekonominé politika, tarptautiné verslo plètra, rizikos valdymas.

JEL KLASIFIKACIJA: F21, G32, H12 